\title{
Adoption and Effectiveness of Insect Pest Management Technologies among Small-Scale Cowpea Farmers in Katagum Local Government Area of Bauchi State
}

\author{
${ }^{1}$ Shehu U. A, ${ }^{2}$ Ibrahim A. I., ${ }^{3}$ Hassan T., \& ${ }^{4}$ Bello M \\ ${ }^{1,23 \& 4}$ Agricultural Education Department School of Undergraduate Studies, P. M. B. 44, College of Education \\ Azare, Bauchi State, Nigeria
}

\begin{abstract}
This paper analyzed Adoption and Effectiveness of Insect Pest Management Technologies among Small-Scale Cowpea Farmers in Katagum Local Government Area of Bauchi State. Data were collected from a sample of 120 Cowpea farmers selected through multi-stage sampling procedure using questionnaire and analyzed using simple descriptive statistics, Ranking and Chi-Square analysis. The result showed that 95.83\% had formal education; $99.17 \%$ were males; $99.17 \%$ were between the ages of 22-52. Majority $87.50 \%$ were married. In terms of farming experience, majority (98.33\%) of the respondent had farming experience between five (5) years and above while $75.00 \%$ had no contact with extension. The result further revealed that $(90.00 \%)$ of the respondents were the head of their households. The result indicated that $75 \%$ and $85 \%$ of the respondents were aware about the use of pesticide and plastic tank, jerry cans etc as insect pest management technology but only $65 \% ; 75 \%$ and $63 \%$; $70 \%$ tried and adopted these technologies to control insect pest in the study area. The respondents were less aware about the use of Neem Seed Extract (16\%), Triple bagging (10 $\%)$ technologies virtually $6 \%$ tried, and $5 \%$ adopted Neem Seed extract as insect pest management technology; while $9 \%$ tried and adopted triple bagging technology in the study area. Majority (52.50\%) of the respondents perceived the technology as effective in controlling insect pest. The result further showed that the Chi-square calculated ( $\left.X^{2} \mathrm{Cal}\right) 12.75$ is less than the Chi-square tabulated $\left(X^{2} \mathrm{Tab}\right.$.) at $10 \%, 5 \%, 1 \%$ probability level. Therefore, the null hypothesis that says there is no significant difference in terms of respondent's perception on the effectiveness of insect pest management technology in improving Cowpea productivity in the study area is accepted. The major problems that affected the effectiveness and adoption of insect pest management technology among small-scale cowpea farmers are Inadequate advise from extension services $(59.17 \%)$; Smaller size of farm land (41.67 \%); High incidence Insect pest (35.00 \%); Inadequate credit facilities (31.67 $\%)$ and Inadequate incentives from government (16.67 \%). It is recommended among others that extension services, incentives from government in the form of subsidizing farm inputs (such as pesticides) and credit facilities be given to improved management of Cowpea in the study area. It is also recommended that the current system of land ownership be reviewed to allow the farmers own larger farmland.
\end{abstract}

\section{Introduction}

The problems of Nigeria's agriculture started right from the country's independence (1960-69). This has been observed evidently from increasing food supply shortfalls and the erratic fluctuations/rising trends of food prices in the country (Gleb and Bienen, 1998). Cowpea, vigna unguiculata is a major source of protein for the majority of people in West Africa including Nigeria. It is the most important legume in West Africa and other tropical area of the world. Cowpea is adjudged the second most important pulse crop in Nigeria after groundnut, commonly grown in small and large quantities in northern Nigeria (Bassey, 2001 in Maunde etal 2005). Cowpea leaves and chaff are good forage used for livestock feeds (Aiyelari, 1993 in Muande et al 2005). Due to the great importance cowpea commands nutritionally, it becomes obvious that more emphasis be place on increase production and attempts be made at obtaining increasingly higher yields per unit area.

Increase in the productivity of cowpea is required to achieve minimal level of food security. Since cowpea is usually grown in the mixtures of cereals crops, increasing the productivity of cowpea in the cereal cowpea farming systems can alleviate poverty in two ways by lowering food prices for cowpea consumers and by raising the incomes of producers. Much of cowpea production takes place in savannah region of the country as the condition favors its growth. The demand of cowpea is increasing while the domestic production is in the hands of small-scale farmers who obtained yield of $200-350 \mathrm{~kg}$ per hectare and in some cases zero yield due to lack of utilization of improved insect pest management technologies available (Singh and Jackai,1985). Singh and Jackai (1985) further submitted that with the use of improved technologies in cowpea production yield of 1,500-2,000kg per hectare could be obtained on sole crops. Employ newly tested innovation of a basic alternative system of farming that guarantees high yields even without the use of some expensive inputs such as fertilizer, now that crude oil price is drifting everyday and we need to protect our source of income to improve 
the living standard of our farmers (Oluwole 2009). Kalu (1994) revealed that agricultural production was about $26 \%$ lower than the level in 1974 and the staple food production (cowpea inclusive) fell by $45 \%$. The decline in export crop production, the low level of agricultural technology, low investments, and inefficient utilization of farm inputs, drought and post harvest losses largely contributed to the poor performance of agricultural sector. This research is to provide an insight into the reasons for the current low production of cowpea in the study area vis a vis the failure to attain self-sufficiency in terms of its production. Singh and Jackai (1985) reported that in some cases zero yields were obtained by farmers due to lack of use of improved technologies available and yield of cowpea is reduced generally due to its susceptibility to many pests. A yield range of $168-672 \mathrm{~kg}$ per hectare had been recorded from farms in Hadejia without any insecticide treatment; while yields of $876-2296 \mathrm{~kg}$ per hectare were recorded from, the same farm when insecticides were timely applied (Gyang, 2004). In Nigeria, an average yield of $189 \mathrm{~kg}$ per hectare have been reported from farmers field compared with $1,500 \mathrm{~kg}$ per hectare on a well managed experimental farm (IITA1999).

In spite of the importance of cowpea in the Nigerian savannah, several biotic and abiotic constraints reduce the grain yield from potential $1,500 \mathrm{~kg}$ per hectare to an average farm yield of $300 \mathrm{~kg}$ per hectare. Drought, a major consequence of climate change, is one of the major causes of yield loss. In addition to draught, striga and pests constitute severe constraints to cowpea production (Ogungbile, 2009). Improving agricultural productivity is founded on identification, distribution and adoption of improved crops varieties and insect pest management technologies because the after higher yield potentials through research, improved early maturing cowpea varieties that are stress tolerant have been developed. It will be interesting to note how far they are adopted.

\section{Problem Statement}

Cowpea, vigna unguiculata is mostly grown in northern parts of the country, in areas such as Katsina, Kano, Jigawa, Bauchi, Gombe, Yobe and Borno State. It is most widely grown in the mixtures of cereal crops. Cowpea is among the most important sources of cheap and available protein in Nigeria (Belel, et. al,. 2014). The by-product is popularly used as animal feeds. Ahmed, (2009) posed that as West Africa's population grows, so does the demand for food, made from nutritious cowpea. Given the current high food demand in Nigeria and the rapid population growth, there is an increasing need to improve the agricultural sector and to expand specifically, local food production to reduce the gap between demand and supply of food. The stakeholders (Shehu, 2009) have attributed Nigeria's food insecurity and poor agricultural production to continued neglect of the sector. He added; 'the oil boom is eroding away, so we must come back to agriculture, which is the back bone of our economy. Time has come to re-dedicate ourselves and bring back the sector to its former glory'.

Pests were serious menace to small-scale cowpea production in the study area. This pest constitutes insects, birds, rodents, monkeys, weeds, bacteria and fungi that feed on the growing plants, injure them, introduce diseases and even kill them (Kolawole et al, 1979; Agrios, 2005). Chemicals used in pest control are known as pesticides. Some extension activities have been made available for farmers to adopt chemical pests control in Nigeria. Few of the advantages of chemical pest control in cowpea production include the fact that it enhances plant vigor and healthy growth, this lead to a higher plant yield and consequently increased productivity and improved quality of harvested crops (Agrios, 2005). However farmers are not presently adopting this allimportant agronomic practice; this may be associated with several constrains.

Research efforts in cowpea over the decades have evolved high yielding varieties, but most varieties released are susceptible to pests. An array of pests has been known to attack cowpea starting from vegetative growth through flowering and podding (fruiting) and storage. During vegetative growth or stage pests such as Aphids (Aphis craccivora), Depoliators (Ootheca mutabilis) are common on most farms. At flowering stage, insects such as Thrips (Megalorothrips josdeti), Moruca pod borer (Moruca testulalis). Pod sucking Bug and during storage the cowpea weevil (Callosobruchus maculates) are common. Substantial yield losses have been recorded in most farms, when farmers do not apply insecticides. Under a high infestation, seed yields of less than $10 \mathrm{~kg}$ ware obtained on farmer's fields (Jackai et al, 1996). Several pests management practices have been developed for farmers, these include the use of improved and disease tolerant varieties, clean seeds, crop rotation, intercropping, insect pest management and farm sanitation among others; it will be interested to note whether they were adopted.

The significant roles played by cowpea production to the income and diet of resource poor farmers, its contribution to the GDP of the state necessitate an evaluation of the adoption and effectiveness of insect pest management practices communicated by the extension agents to farmers. The study is important in view of the significant yield loss recorded on most farms after the use of pest's management strategies. This development may be traced to problems associated with pesticides ineffectiveness, pests' resurgence and unreliability of the source of agro-chemicals. It is expected that the outcome of this study will assist policy makers to redesign strategies to reduce menace associated with poor management of pest on farmers' field.

The specific objectives of the study were: 
1. To examine the socioeconomic characteristics of cowpea farmers,

2. To evaluate adoption, effectiveness and the level of awareness of the insect pests management technologies by cowpea farmers,

3. To identify constrains to adoption of insect pest management technology faced by cowpea farmers.

\section{The Study Area And Data Collection}

Katagum is one of the twenty local governments currently present in Bauchi State. Katagum local government covers a savannah land area of about 1120 square kilometers with its headquarters at Azare, the second largest town in Bauchi State. It comprises of three (3) districts namely; Madara, Chinade and Azare district area (Abdulkadir, 2000). The local government headquarters is about 200 kilometers to Bauchi, the state capital, also the same kilometers to Kano. Islam is the dominant religion in the study area. The local government has a population of 330,052peoples (NPC, 2006). This figure comprises of various tribes but notable among them are the Hausa's, Fulani's and Kanuri's, however, Hausa is the most commonly used language in the study area. The people of the local government are predominantly farmers and they cultivated crops such as millet, sorghum, cassava, wheat, sugarcane, and groundnut, cowpea etc.

\section{Sampling Technique}

Multi-stage sampling technique was used to get respondents in the study area. The local government is made up of ten (10) district Azare, Nasarawa, Madangala, Chinade,Bulkachuwa, Yayu, Budir, Buskuri, Ragwam and Madara and five (5) districts were purposively selected because if their prominence in cowpea production. From the sampled districts three (3) villages were randomly selected and eight (08) farmers were randomly sampled from each from each of the villages selected. Therefore, a total of one hundred and twenty (120) farmers were randomly sampled from the fifteen (15) villages throughout the research period. The sampled villages include Fatara, Garin-Bakake, Bagaje, Nasarawa, Bidawa, Matsango, Madangala, Kakudi, Kujuru, Buskuri, Barkeji, Dolori, Ragwam, Magwanshi and Lafiya. Structured questionnaires were used to collect data from the farmers on the effectiveness and adoption techniques of insect pest management technologies during the 2015 production season. Data on socioeconomic variables such as age, sex, farm size, farming experience etc were also collected.

\section{Data Analytical Techniques}

Descriptive statistics was used to describe the socio-economic characteristics of farmers. Data collected has been summarized and subjected to statistical analysis such as descriptive statistics, percentages and inferential statistics such as Chi-square were used to assess the effectiveness of insect-pests management technologies with the aid of Likert opinion scaling method. Also for adoption studies Likert scaling and Statistical Package for Social Sciences (SPSSvs.20) was used to analyze the data.

Chi-Square $\left(\mathbf{X}^{2}\right)$

The Chi-Square $\left(\mathrm{X}^{2}\right)$ test were used to whether there is significant difference between the expected frequencies and the observed frequencies in one or more categories (Anne, 2005). It is a measurement of how expectation compared to result. Chi-Square $\left(\mathrm{X}^{2}\right)$ is calculated as the sum of the squares of observed values minus (-) expected values divided by expected values.

$$
\mathrm{X}^{2}=\sum(\mathrm{Fo}-\mathrm{Fe})^{2}
$$

$\mathrm{Fe}$

Where; $\mathrm{X}^{2}=$ Chi-Square

$$
\text { Fo = Observed frequency }
$$

$\mathrm{Fe}=$ Expected frequency

The determinant of perception used was the effectiveness of the technology in improving the farmers Cowpea productivity. A five point Likert Type Scale (1= highly ineffective, $2=$ ineffective, $3=$ undecided, $4=$ effective, $5=$ highly effective) was used to analyzed the data.

Hypothesis:

Ho: there is no significant difference in terms of farmers perception on the effectiveness of insect pest management technology in improving Cowpea productivity in the study area.

$\mathrm{H}_{1}$ : there is a significant difference in terms of farmers perception on the effectiveness of insect pest management technology in improving Cowpea productivity in the study area.

\section{Socio-economic characteristics of respondents}

\section{Results And Discussion}

Socio-economic class may be defined as relatively permanent and homogeneous division in a society into which individuals or families sharing similar values, lifestyle, interest and behaviors can be categorized (Gbakeji and Rilwan, 2009). Socio-economic characteristics are the measures of an individual's or household's economic and social positions based on education, income and occupation etc. it usually assist in getting a clear 
understanding of their behavior as well as providing a clue towards explaining their personality that could improve their efficiency and productivity.

Table 1: Socio-Economic Characteristics of the Respondents in the Study Area (N=120).

\begin{tabular}{|c|c|c|c|c|c|c|}
\hline Variable & Freq. & Percentage & Min. & Max. & Mean & Std. deviation \\
\hline Age(yrs) & & & 22 & 66 & 44.2 & 8.10 \\
\hline $21-30$ & 25 & 20.83 & & & & \\
\hline $31-40$ & 34 & 28.33 & & & & \\
\hline $41-50$ & 50 & 41.67 & & & & \\
\hline $51-60$ & 10 & 08.33 & & & & \\
\hline$>60$ & 01 & 0.83 & & & & \\
\hline Total & 120 & 100 & & & & \\
\hline Household size (No.) & & & 03 & 26 & 17 & 3.5 \\
\hline $02-05$ & 02 & 01.67 & & & & \\
\hline 06-09 & 05 & 04.17 & & & & \\
\hline $10-13$ & 12 & 10.00 & & & & \\
\hline $14-17$ & 40 & 33.33 & & & & \\
\hline $18-21$ & 45 & 37.50 & & & & \\
\hline 22 and above & 16 & 13.33 & & & & \\
\hline Total & 120 & 100 & & & & \\
\hline Farming experience (yrs) & & & 04 & 25 & 16 & 3.8 \\
\hline$<5$ & 02 & 1.67 & & & & \\
\hline $6-10$ & 12 & 10.00 & & & & \\
\hline $11-15$ & 35 & 29.17 & & & & \\
\hline $16-20$ & 50 & 41.67 & & & & \\
\hline$>20$ & 21 & 17.50 & & & & \\
\hline Total & 120 & 100 & & & & \\
\hline Farm size (ha) & & & 0.5 & 8 & 1.5 & 1.7 \\
\hline$<1$ & 10 & 08.33 & & & & \\
\hline $1-2$ & 97 & 80.84 & & & & \\
\hline $3-4$ & 10 & 08.33 & & & & \\
\hline$>5$ & 03 & 02.50 & & & & \\
\hline Total & 120 & 100 & & & & \\
\hline
\end{tabular}

Source: survey data, 2015

Table 1: represents the socio-economic characteristics of the respondent. The study revealed that the average age of the farmer in the study area is 44 years with a minimum and maximum age(s) of 22 and 66 respectively. The result further revealed that majority of the respondents $(99.17 \%)$ are in their active stage between 22-52 years of age which is the stage for economic growth and productivity; age of an individual make him mentally mature and able to take rational decision (Khan, 1991). The result revealed that the average household size of the respondents is 17 persons that are far above the national average (5-7 persons per household) with minimum of 3 and a maximum of 26 persons per household. The result disclosed that the mean farming experience of the respondents is 16 years. Majority of the respondents $(98.33 \%)$ had farming experience of 5 years and above. Majority $(89.17 \%)$ of the respondents in the study area were small-scale farmers having small fragmented holdings farm size below two (2) hectares. Minimum and maximum size of land cultivated were 0.5 and 8 hectares while 1.5 is the mean and 1.7 as standard deviation for farm size.

\section{Qualitative Socio-economic Variables used in this Study}

It describe the distribution of respondents based on educational level, marital status, gender, contact with extension agent and status of the respondents in a household.

The study revealed that $33.33 \%$ of the respondents had qur'anic education, while $29.17 \%$ of the respondents had primary education, $25.00 \%$ of the respondents had secondary education, only $08.33 \%$ of the respondents had tertiary education, implying that majority of the respondents ware literate.

Majorities $(87.67 \%)$ of the respondents were married and almost all the farmers ware males as females virtually concentrates on their domestic activities, this conform to the norms and values of that society. High proportion (75.00\%) of the respondents had no contact with extension services, showing that they may not get the improved techniques of farming compared to the $25.00 \%$ that had contact and may likely adopt modern technique of farming.

The result further revealed that $(90.00 \%)$ of the respondents were the head of their households, while the remaining $(10.00 \%)$ of the respondents were members in their households as such representing their heads for this study. 
Table 2: Qualitative Socio-Economic Characteristics of the Respondents $(\mathrm{N}=120)$.

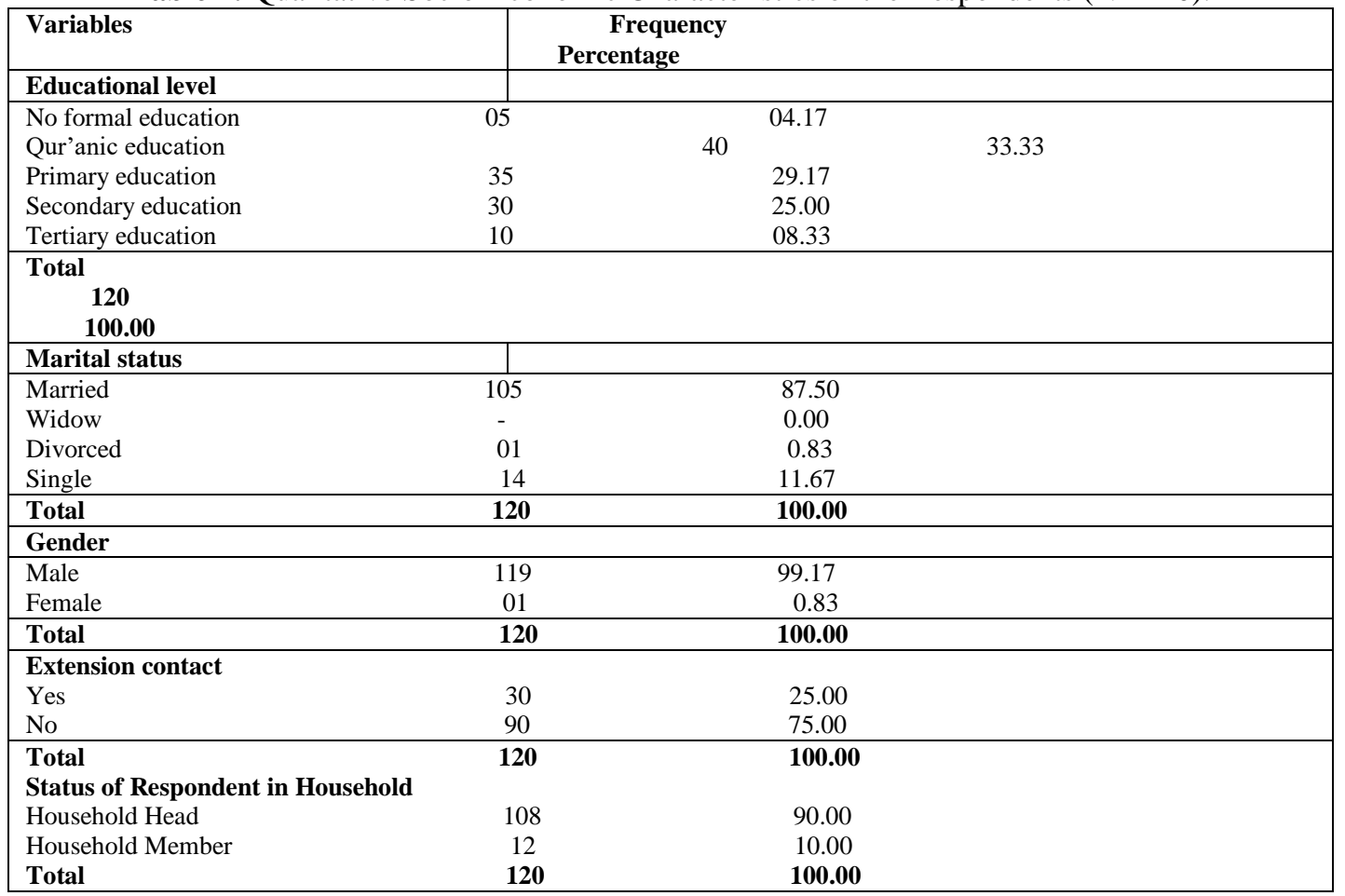

Source: survey data, 2015

\section{Awareness, Trial and Adoption of Insect Pest Management Technology}

The result in table 3 above indicated that $75 \%$ and $85 \%$ of the respondents were aware about the use of pesticide and plastic tank, jerry cans etc as insect pest management technology but only $65 \% ; 75 \%$ and 63 $\% ; 70 \%$ tried and adopted these technologies to control insect pest in the study area. The respondents were less aware about the use of Neem Seed Extract (16\%), Triple bagging (10\%) technologies virtually $6 \%$ tried, and 5 $\%$ adopted Neem Seed extract as insect pest management technology; while $9 \%$ tried and adopted triple bagging technology in the study area The extent of technology adoption or rejection depends on the respondent's behaviour. There are a number of factors that influence the extent of adoption of technology which include characteristics or attributes of the technology, the clientele who is the object of change, the change agent, socio-economic factors, biological and physical environmental in which the technology take place (Ngoc Chi and Yamada, 2002).

Table 3: Distribution of the Respondents based on Awareness, Trial and Adoption of Insect Pest Management Technology in the Study Area $(\mathrm{N}=120)$.

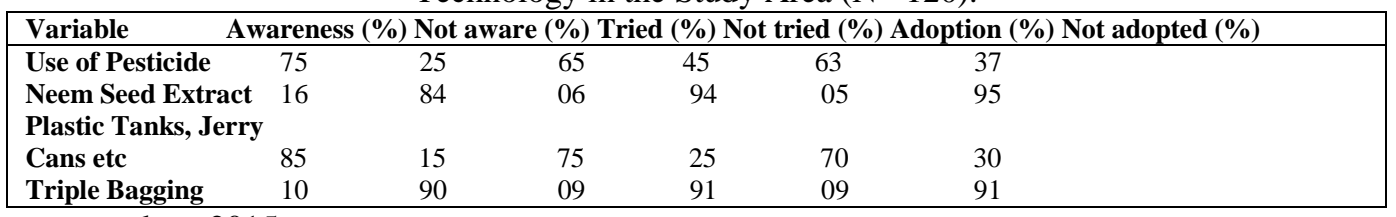

Source: survey data, 2015

\section{Respondents Perception on the Effectiveness of the Insect Pest Management Technology}

Respondents might have varied perception on the effectiveness of Insect Pest Management Technology in the Study Area. The results in table 4 revealed that majority $(52.50 \%)$ of the respondents perceived the technology as effective in controlling insect pest, only $0.83 \%$ of the perceived the technology as highly effective, while $25.83 \%$ and $13.33 \%$ of the respondents perceived the technology as ineffective and highly ineffective Cowpea insect pest. The result further showed that the Chi-square calculated ( $\left.\mathrm{X}^{2} \mathrm{Cal}\right) 12.75$ is less than the Chi-square tabulated $\left(\mathrm{X}^{2} \mathrm{Tab}\right.$.) at $10 \%, 5 \%, 1 \%$ probability level. Therefore, the null hypothesis that says there is no significant difference in terms of respondent's perception on the effectiveness of insect pest management technology in improving Cowpea productivity in the study area is accepted. This is not surprising because the small numbers of farmers that tried and adopted this technology have higher output thus have more profit. This result agree with (Abdul'azeez, 2013) who reported that farmers in the study area perceived that 
integrated soil fertility management technology package as effective as a result of cost and return showed higher gross margin for experimental plots as compared to farmers practices.

Table 4: Respondents Perception on the Effectiveness of the Insect Pest Management Technology in the Study Area $(\mathrm{N}=120)$.

\begin{tabular}{|c|c|c|c|c|c|c|c|}
\hline \multicolumn{2}{|c|}{ Perception } & Azare $\mathbf{N}$ & Nasarawa & Madangala & Buskuri & Ragwam & Total \\
\hline \multicolumn{2}{|c|}{ Highly effective } & 0 & 0 & 0 & 0 & 1 & $01(0.83)$ \\
\hline \multicolumn{2}{|l|}{ Effective } & $14(58.33)$ & 13 (54.17) & 14 (58.33) & $12(50.00)$ & $10(45.83)$ & $63(52.50)$ \\
\hline \multicolumn{2}{|c|}{ Undecided } & $1(4.17)$ & $2(8.33)$ & $1(4.17)$ & $2(8.33)$ & $3(12.50)$ & $09(7.50)$ \\
\hline \multicolumn{2}{|c|}{ Ineffective } & $5(20.83)$ & ) $3(12.50)$ & $6(25.00)$ & $8(33.33)$ & $9(37.50)$ & $31(25.83)$ \\
\hline \multicolumn{2}{|c|}{ Highly Ineffective } & 4 (16.67) & $6(25.00)$ & $3(12.50)$ & $2(8.33)$ & $1(4.17)$ & $16(13.33)$ \\
\hline Total & & $24(20.00)$ & $24(20.00)$ & $24(20.00)$ & $24(20.00)$ & $24(20.00)$ & $24(20.00)$ \\
\hline $\mathrm{X}^{2} \mathrm{Cal}$ & 12.75 & & & & & & \\
\hline Df & 10 & & & & & & \\
\hline Sig & 0.647 & & & & & & \\
\hline Decision & NS & & & & & & \\
\hline
\end{tabular}

Source: survey data, 2015

\section{$\mathrm{X}^{2}$ Tabulated @ $0.10=20.30 ; 0.05=22.96$ and $0.01=24.52 ; \mathrm{NS}=$ Not Significant \\ NB: Figures in Parenthesis () are percentages \\ Constrains to Effectiveness and Adoption of Insect Pest Management Technology among Small-Scale Cowpea Farmers}

The major problems that affected the effectiveness and adoption of insect pest management technology among small-scale cowpea farmers are Inadequate advise from extension services (59.17\%); Smaller size of farm land (41.67 \%); High incidence Insect pest (35.00\%); Inadequate credit facilities $(31.67 \%)$ and Inadequate incentives from government $(16.67 \%)$

Table 5: Constrains to Effectiveness and Adoption of Insect Pest Management Technology among Small-Scale

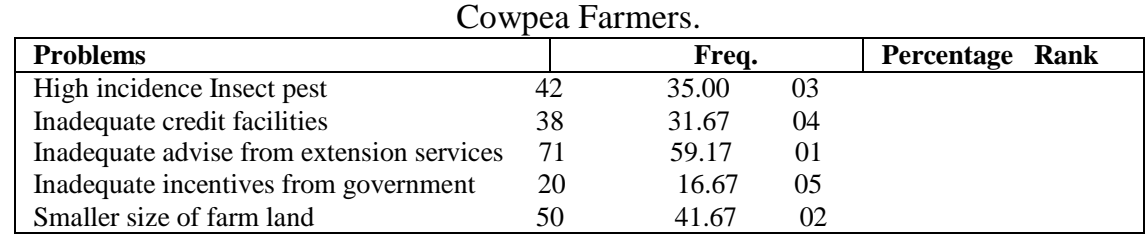

Source: survey data, 2015

NB: Multiple responses allowed

\section{Conclusion And Recommendations}

Adoption and effectiveness of insect pest management technologies among small-scale cowpea farmers in Katagum Local Government Area of Bauchi State was examined. The respondents were in their active stage, married, experience and have high dependant with less extension contact. Out of four technologies, the respondents were strongly aware about two technologies, perceived the technologies as effective in controlling insect pest and adopted the technology (pesticide and plastic tank, jerry cans etc). The respondents were less aware about Neem Seed Extract and Triple bagging Technologies as an insect pest management technique but the small number of respondents that are aware tried it and adopted the technologies. It is recommended among others that extension services, incentives from government in the form of subsidizing farm inputs (such as pesticides) and credit facilities be given to improved management of Cowpea in the study area. It is also recommended that the current system of land ownership be reviewed to allow the farmers own larger farmland.

\section{References}

[1]. Abdulkadir, A. (2002), "Geographical Features of Katagum Emirate" in Azare, G.D. (Ed.) The Premier School in Katagum Emirate: A Documentary History of Central Science Primary School Azare. Pp 2-6

[2]. Abdul'azeez, H. W. (2013). Economics of AGRA On-farm Cereal Legume Strip Cropping System in Kano State, Nigeria. Unpulished M. Sc Dissertation Submitted to the Department of Agricultural Economics and Extension, Bayero University, Kano Nigeria. Pp 24

[3]. Agrios, G.H. (2005). Plant Pathology. Fifth edition. New York, U.S.A.: Academic Press, 45 p.

[4]. Ahmed, I. (2009). Gatsby Crop - Livestock Project to Improve Cowpea production in Niger posted on www.wwenglish.com/en.voa/stan/2009/ 03/2009040231002.htm

[5]. Anne, F. (2005) Mabun from "Statistics for the Social Science" by Vicky Sharp. (13 September, 2005). Chi-Square Test. The environmental Literary Council, 2002

[6]. Belel, M. D. , Halim ,R. A., Rafii,M. Y. \& Saud, H. M. (2014). Intercropping of corn with some selected legumes for improved forage production: A review; Journal of Agricultural Science; 6(3) 19-30

[7]. Gbakeji, J.O. and Rilwan, M. L. (2009). Residents Socioeconomic Characteristics and the Residential Mobility Process in an Urban Space: The Example of Warri Metropolis, Delta State, Nigeria. Jpurnal of Ecology, 27 (1): 46-51 
[8]. Gleb, A. and Bienen, H. (1998), "Nigeria: From Windfall Gains to Welfare Losses” In: Allen Gleb (ed). Oil Windfalls Blessing or Curse? Oxford University Press. Pp. 227-259.

[9]. Gyang, P.H. (2004), Problems and Prospects of Cowpea Production and Marketing, A Case Study of Ningi L. G. A. Bauchi State. Unpublished N. C. E. Project, College of Education Azare Bauchi state. Pp. 10-15.

[10]. Singh, S.R. and Jackai, E.M. (1985). "Insect Pests of Cowpea in Africa: Their Lifecycle, Economic Importance and Potential for Control" in Singh, S.R. and Rachie, K.O. (eds.), Cowpea Research, Production and Utilization (CRPU), S.R. John Wiley and Sons Ltd. Pp217 - 231.

[11]. Kalu,C. V. (1994). The Nigerian Condition: Arthur Nwankwo's View Point and Blue Prints. Lagos, Nigeria.: Fourth Dimension Publishers, $248 \mathrm{p}$.

[12]. Kolawole, M. F; Adegbola, A. A; Anos, L. and Ashaye, T. I. (2009). Agricultural Science for Schools and Colleges. Ibadan, Nigeria.: University Press Limited, 35-56p.

[13]. Khan, M. K. (1991). An Analysis of the Impact of Extension Work of hill Farming Development of Maize Production in Tehsil Muzaffarabad, Azad State of Jammu and Kashmir. M. Sc. Thesis, Rural Sociology, University of Agriculture, Faisalabad. Pp. 21

[14]. Muande et al(2005). Investigation of Physio-Mechanical Properties of Two Cowpea Varieties. Journal of Agricultural Technology, National Board for Technical Education, Kaduna-Nigeria. pp 31.

[15]. N.P.C. (2006). Household Enumeration and Head count, National population commission. Abuja, Nigeria.

[16]. Ngoc Chi T. and Yamada, R. (2002). Factors Affecting Farmers Adoption of Technologies in Farming System: A Case Study of Omon District, Can Tho Province, Mekong Delta. Omonrice, 10:94-99.

[17]. Singh, S.R. and Jackai, E.M. (1985), "Insect Pests of Cowpea in Africa: Their Lifecycle, Economic Importance and Potential for Control" in Singh, S.R. and Rachie, K.O. (eds.) Cowpea Research, Production and Utilization (CRPU), S.R. John Wiley and Sons Ltd. Pp217-231

[18]. Shehu, U. A; (2009). Efficiency of Resource-use in Small-Scale Sorghum Production for the Achievement of National Food Security: A Case Study of Katagum Local Government, Bauchi State. Being a Paper Presented at the $8^{\text {th }}$ School of Art \& Social Sciences National Conference C. O. E. Azare, on $3^{\text {rd }}-5^{\text {th }}$ August, 2010.

[19]. Oluwole A. (2009), We can produce more food without fertilizer. Daily Sun News Paper, Monday may 4, $2009 . P p .21$.

[20]. Ogungbile, A. O. (2009). Cowpea Production System in Sudan Savanna Zone of Nigeria, Unpublished material. 